\title{
GASTRIC CARCINOMA WITH OSSEOUS METAPLASIA IN A DOG
}

\author{
Irina Amorim¹, Célia Lopes¹, Rui Gil da Costa1', Augusto Faustino¹, Fátima Gärtner², \\ Patrícia Dias Pereira ${ }^{1}$ \\ 1 Instituto de Ciências Biomédicas de Abel Salazar da Universidade do Porto (ICBAS-UP), Portugal \\ 2 Instituto de Patologia e Imunologia da Universidade do Porto (IPATIMUP) e Instituto de Ciências \\ Biomédicas de Abel Salazar (ICBAS-UP), Portugal \\ Correspondência: Irina Amorim: irinamorim@hotmail.com
}

\begin{abstract}
This report describes an unprecedented case of a gastric carcinoma with osseous metaplasia in an 8-year-old male Standard Poodle. An exploratory laparotomy revealed a firm yellowish nodular mass in the pyloric region. The lesion was surgically removed and submitted for current histological examination. Immunohistochemistry was performed employing monoclonal antibodies for pan-cytokeratin, vimentin, smooth muscular $\alpha$-actin and BMP-2/4. The mass consisted in neoplastic proliferation of epithelial cells, arranged in a tubular or acinar pattern and supported by scirrhous stroma, with mucin production and multiple foci of heterotopic ossification. Neoplastic epithelial cells showed strong positive immunostaining for AE1/AE3 and BMP-2/4, although they were negative for both vimentin and $\alpha$-actin. Histopathological findings suggested that the bone tissue may be primarily originated from neoplastic epithelial cells which directly circumscribe the osseous metaplasia foci.
\end{abstract}

Key Words: canine; bone morphogenetic proteins (BMPs); gastric carcinoma; immunohistochemistry; osseous metaplasia

\section{CARCINOMA GÁSTRICO A METAPLASIA ÓSSEA EM UM CÃO}

RESUMO: Neste artigo descreve-se um caso inédito de um carcinoma gástrico com metaplasia óssea num caniche macho, de oito anos de idade. Através de laparatomia exploratória foi cirurgicamente removida uma massa amarelada, nodular e firme na região do piloro. A lesão foi enviada para análise histopatológica. Foram realizadas técnicas imunohistoquímicas adicionais, sendo empregues os seguintes anticorpos monoclonais: pan-citoqueratinas, vimentina, alfa-actina do músculo liso e BMP-2/4. A massa consistia numa proliferação neoplásica de células epiteliais, dispostas em arranjos tubulares ou acinares por entre estroma esquirroso, apresentando áreas de deposição de mucina e múltiplos focos de ossificação heterotópica. As células epiteliais neoplásicas demonstraram forte imunopositividade para a AE1/AE3 e BMP-2/4, não tendo apresentando qualquer imunorreactividade para a vimentina e alfa actina do músculo liso. Os achados histopatológicos sugerem que o tecido ósseo neoformado deve ser principalmente proveniente das células epiteliais neoplásicas que circunscrevem diretamente os focos de metaplasia óssea existentes na lesão.

Palavras-chave: canina; proteínas morfogenéticas ósseas (BMPs), carcinoma gástrico; imunohistoquímica; metaplasia óssea 


\section{INTRODUCTION}

Gastric tumours account for less than $1 \%$ of all reported neoplasms in dogs (Crow, 1985). Carcinoma is the most frequent canine gastric neoplasm, followed by smooth muscle tumours and lymphomas (Head, 1976). Benign glandular tumours are less common, being generally found as incidental lesions at necropsy (Scanziani et al., 1991). Most gastric carcinomas are located in the lesser curvature and pylorus, often progressing to involve most of the stomach body (Fonda et al., 1989; Scanziani et al., 1991, Sautter et al., 1975; Sullivan et al., 1987).

The average age of dogs with gastric carcinoma ranges from 7.5 to 10.2 years (Fonda et al., 1989). Some authors report a higher incidence in males (Fonda et al., 1989; Scanziani et al., 1991) and suggest a breed predisposition in Rough Collie, Staffordshire Terrier (Sullivan et al., 1987) and Belgian Shepherd (Sautter et al., 1975). Early clinical signs include vomiting, weight loss, anorexia, diarrhoea, melena, hematemesis and dullness (Ogilvie et al., 1995).

\section{MATERIAL AND METHODS}

This short communication describes an unprecedented case of gastric carcinoma with osseous metaplasia in an 8-year-old male Standard Poodle. The animal was presented for clinical examination with a 2-week history of vomiting (mostly in the morning), not related to food intake, and abdominal pain. No substantial haematological and biochemical changes were observed but on abdominal ultrasound examination a diffuse mass in the gastric region was revealed. An exploratory laparotomy confirmed a firm pyloric mass, with multiple yellow nodulations. The lesion was surgically removed, fixed in 10 per cent buffered formalin and submitted for histological examination. Supportive treatment failed and the animal was euthanatized 1-week later upon the owner's request, who did not allow necropsy examination.

Tissues samples were routinely processed, dehydrated and embedded in paraffin wax. Consecutive $4 \mu \mathrm{m}$ sections were cut and stained with haematoxylin and eosin. Immunohistochemistry was performed using the avidin-biotin-peroxidase complex $(A B C)$ method, employing the following monoclonal antisera: pancytokeratin (clone AE1/AE3, Zymed) diluted 1:50; vimentin (clone V9, Dako) diluted 1:100; smooth muscular $\alpha$-actin (clone HHF35, Dako) diluted 1:300 and bone morphogenetic protein 2/4 (BMP2/4) (clone H51, Santa Cruz) diluted $1: 20$.

\section{RESULTS}

Histologically, the mass consisted of a multinodular neoplastic proliferation of well-differentiated epithelial cells, arranged in a tubular or acinar pattern supported by scirrhous stroma. Neoplastic cells presented large, round to oval nuclei, with a finely stippled chromatin pattern, exhibiting one or two prominent nucleoli and abundant acidophylic cytoplasm. Some of these cells adopted a mucin-filled signet-ring morphology. Extracellular mucin overproduction was also observed as large irregular pools. Mitotic figures were frequent (six mitotic figures per high power field) some of which were atypical. Multiple foci of heterotopic ossification, consisting of osteoid and fully matured bone tissue, surrounded by neoplastic epithelial cells (Fig 1), were identified both in the mucosa and muscular layers. Neither cytological atypia nor mitotic figures were found in those osseous foci suggesting that they 
were of metaplastic origin and did not constitute the neoplastic population.

Fig $1 \mathrm{~A}$ - Mature bone tissue surrounded by gastric neoplastic epithelial cells $\mathrm{HE}, 10 \mathrm{x}$. Bar $=100 \mu \mathrm{m}$.

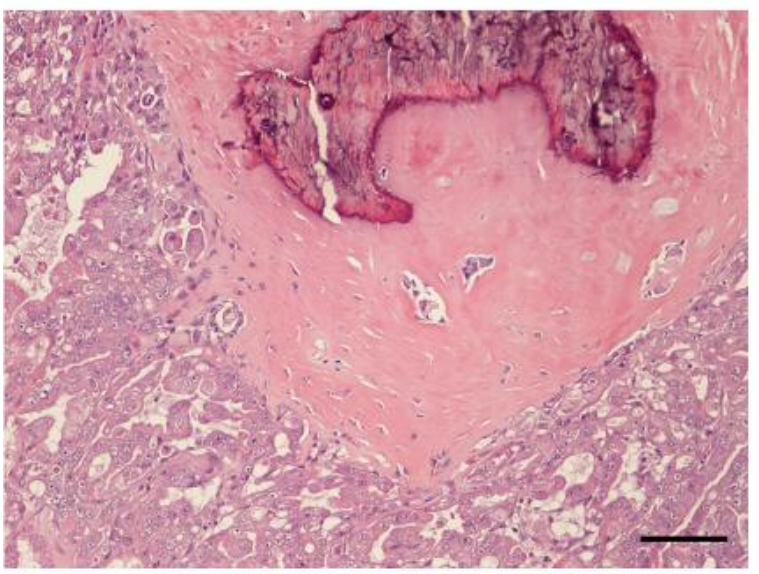

Fig 18 - Multiple foci of heterotopic ossification in gastric mucosa. HE, 10x. Bar $=100 \mu \mathrm{m}$.

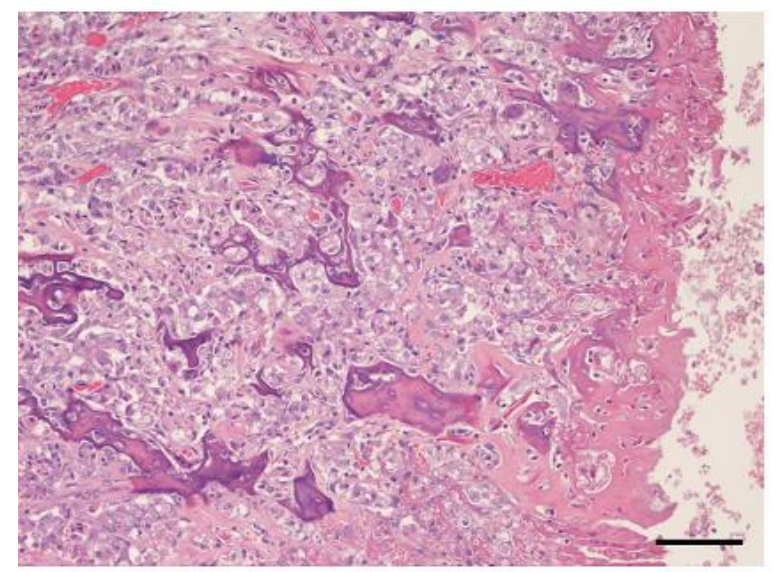

Fig 2 - Positive immunostaining for antibody anti-BMP2/4. HE, 20x. $\mathrm{Bar}=100 \mu \mathrm{m}$.

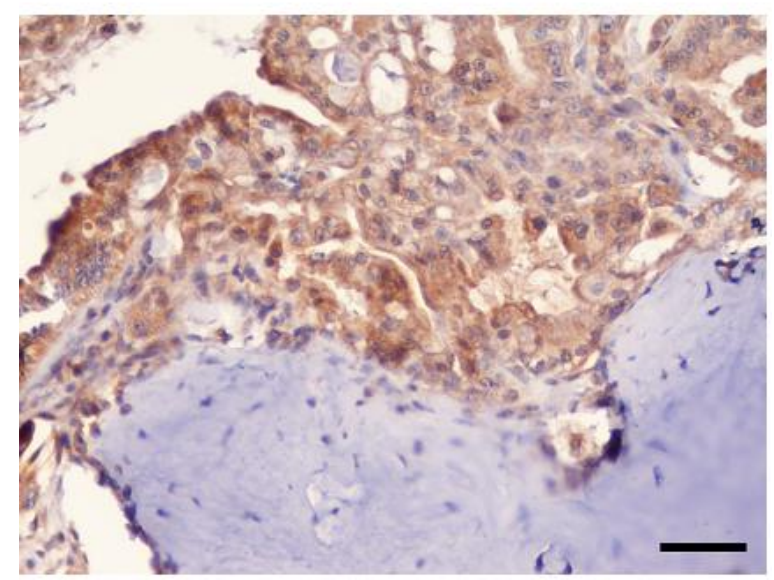

Neoplastic cells showed strong positive immunostaining for AE1/AE3 and BMP-2/4 (Fig. 2), but not for vimentin and smooth mucular $\alpha$-actin, while osteoblasts showed only weak cytoplasmic immunoexpression for BMP-2/4. Multiple neoplastic epithelial emboli were also observed. Based on histopathological findings a diagnosis of gastric carcinoma with osseous metaplasia was made.

\section{DISCUSSION}

According to the World Health Organization (WHO), canine gastric carcinomas are subdivided into tubulopapillary, mucinous, signet-ring and undifferentiated types, depending on the predominant histological picture (Head et al., 2003). The WHO classification system also includes carcinosarcoma (involving both epithelial and mesenchymal malignant components, sometimes with chondroid/osseous differentiation) as a rare gastric neoplasm (Teramachi et al., 2003). In the case here reported, neoplastic cells showed immunoreactivity for the epithelial marker but not for vimentin or $\alpha$-actin, thus excluding a putative mesenchymal origin. Moreover, the non-neoplastic appearance of the osseous foci ruled out a possible sarcomatous component.

$$
\text { According to several }
$$
investigations, osseous metaplasia has been associated with inflammatory changes and mucin production and (Alper et al., 2000; Haque et al., 1996), local ischemia and/or necrosis (Ansari et al., 1992). However, although these events occur frequently in gastric carcinomas, osseous metaplasia remains an unusual finding, with only very few cases reported in humans (Olinici et al., 2002). In veterinary medicine, osseous metaplasia in a gastric carcinoma has only been described in ferrets (Mustela putoris furo) (Nakanishi et al., 2005) and in pleural and aortic metastases of a gastric carcinoma in a camel (Camelus ferus bactrianus) (Kunh et al., 2003). 
The origin of heterotopic ossification in gastrointestinal carcinomas is not well understood, and some investigators suggest direct osseous metaplasia from carcinomatous cells (Plenge, 1955), while others speculate it may derive from stromal fibroblasts (Rhone \& Horowitz, 1976).

Some studies demonstrated the existence of tumour related factors with osteogenic properties - BMP's - that may be involved in the formation of osseous areas, both within the tumour and in metastatic lesions (Goltzman, 1997; Komai et al., 2006; Liu et al., 2007). BMP's are a group of proteins belonging to the transforming growth factor-beta superfamily, present in the bone matrix and recently 16 different BMP's have been identified and subdivided according to their structural similarity (Dimitriou \& Giannoudis, 2005). When binding to the appropriate receptors, they promote mesenchymal cell differentiation into osteoblasts leading to bone formation (Wang et al., 1990; Dimitriou \& Giannoudis, 2005). BMP-2 and BMP-4 are closely related molecules and both have the ability to induce ectopic bone formation in vivo and osteoblastic differentiation (Wang et al, 1990; Hanada et al, 1997). Moreover, Kypson et al. (2003) documented that heterotopic ossification in a human rectal carcinoma was associated with an BMP-2 overexpression in epithelial neoplastic cells. Thus, it has been proposed that both neoplastic epithelial and mesenchymal cells can produce signalling proteins such as BMP's, leading to heterotopic ossification areas within tumoral lesions (Liu et al., 2007).

In this case, the positive immunostaining of carcinomatous component for BMP suggests the presence of an osteogenic signal originated from neoplastic epithelial cells. This fact was reinforced by the evidence that in normal gastric tissues (representing the different anatomical areas of canine stomach) no imunoexpression of BMP2/4 was found neither in epithelial nor in mesenchymal cells. Therefore, we hypothesize that the bone tissue derived directly from neoplastic epithelial cells that circumscribe the osseous metaplasia foci, creating an autocrine or paracrine signal which probably induced the differentiation of epithelial, mesenchymal or stem cells into osteoblasts.

The reason why some neoplasms undergo osseous metaplasia while others do not is unknown, but it is probably a result of a random activation with very little growth advantage for neoplastic cells (Kypson et al., 2003). Otherwise, it would be a more commonly finding.

\section{CONCLUSION}

In this report we describe the first case of gastric carcinoma with osseous metaplasia in a dog and demonstrate for the first time the expression of BMP-2/4 within the epithelial neoplastic cells of a canine gastric carcinoma, revealing a potential signalling mechanism for osteogenic transformation.

\section{ACKNOWLEDGMENT}

The authors would like to thank Professor C.D. Olinici who kindly provided bibliographic support.

\section{REFERENCES}

ALPER, M.; AKYUREK, N.; PATIROGLU, T. et al. Heterotopic bone formation in two cases of colon carcinoma. Scandinavian Journal of Gastroenterology, n.35, p.556-558, 2000.

ANSARI, M.; SACHS, I.; MAX, E. et al. Heterotopic bone formation in rectal carcinoma. Case report and literature review. Digestive Diseases and Sciences, n.37, p.1624-1629, 1992. 
CROW, S. Tumors of the alimentary tract. The Veterinary Clinics of North America. Small Animal Practice, v.1, n.3, p.577-596,1985.

DIMITRIOU, R.; GIANNOUDIS, P. Discovery and development of BMPs. Injury: International Journal of the Care of the Injured, v.36, n.1, p.28-33, 2005.

FONDA, D.; GUALTIERI, M.; SCANZIANI, E. Gastric carcinoma in the dog: a clinicopathological study of 11 cases. Journal of Small Animal Practice, v.30, n.4, p.353-357, 1989.

GOLTZMAN, D. Mechanisms of the development of osteoblastic metastases. Cancer Supplement, v.80, p.1581-1587, 1997.

HANADA, K.; DENNIS, J.; CAPLAN, A. Stimulatory effects of basic fibroblast growth factor and bone morphogenetic protein-2 on osteogenic differentiation of rat bone marrow derived mesenchymal stem cells. Journal of Bone and Mineral Research, v.12, n.10, p.1606-1614, 1997.

HAQUE, S.; EISEN, R.; WEST, A. Heterotopic bone formation in the gastrointestinal tract. Archives of Pathology and Laboratory Medicine, v.120, n.36, p.653-656, 1996.

HEAD, K. Tumors of the lower alimentary tract. Bull World Health Organization, v.53, n.2-3, p.167-186, 1976.

HEAD, K.; CULLEN, J.; DUBIELZIG, R. et al. Histological classification of the tumors of the alimentary system of domestic animals. World Health Organization International Histological Classification of Tumors of Domestic Animals, 2nd series, vol. 10, AFIP, Washington DC., 2003, p.75-78.

KOMAI, Y.; MORIMOTO, S.; SAITO, K. et al. Possible involvement of bone morphogenetic protein 2 in heterotopic ossification in metastatic lesion from urothelial carcinoma of bladder.

International Journal of Urology, v.13, p.11261128, 2006.

KYPSON, A.; MORPHEW, E.; JONES, R. et al. Heterotopic ossification in rectal cancer: Rare finding with a novel proposed mechanism. Journal of Surgical Oncology, v. 82, n.2, p.132-137, 2003.

KUNH, N.; GRONE, A.; PAGAN, O. et al. Metastatic gastric adenocarcinoma and diffuse hyperplastic gastritis resembling human Menetrier's disease in a camel (Camelus ferus bactrianus). Journal of Veterinary Medicine. A, Physiology, Pathology, Clinical Medicine, v.50, n.7, p.359-362, 2003.
LIU, K.; TRIPP, S.; LAYFIEL, L. Heterotopic ossification: Review of histological findings and tissue distribution in a 10-year experience. Pathology Research \& Practice, v.203, n.9, p.633-640, 2007.

NAKANISHI, M.; KUWAMURA, M.; YAMATE, J. et al. Gastric adenocarcinoma with ossification in a ferret (Mustela putorius furo). Journal of Veterinary Medicine Science, v.67, n.9, p.939941, 2005.

OGILVIE, G.; MOORE, A. Gastrointestinal tumors. In: Managing the Veterinary Cancer Patient: A Practice Manual. Trenton, Veterinary Learning System; 1995, p.351.

OLINICI, C.; DOMSA, I.; DRAGHICI, A. et al. Heterotopic bone formation in gastric carcinoma. Case report and discussion of the literature.

Romanian Journal of Gastroenterology, v.11, n.4, p.331-333, 2002.

PLENGE, K. Über Knochenbildung in Karzinomen. Zentralblatt fürt Allgemeine und Pathologische Anatomie, v.93, p.160-167, 1955.

RHONE, D.; HOROWITZ, R. Heterotopic ossification in the pulmonary metastases of gastric adenocarcinoma: report of a case and review of the literature. Cancer, v.38, n.4, p.1773-1780, 1976.

SAUTTER, J.; HANLON, G. Gastric neoplasms in the dog: a report of 20 cases. Journal American Veterinary Medical Association, v.166, n.7, p.691-696, 1975.

SCANZIANI, E.; GIUSTI, A.; GUALTIERI, M. et al. Gastric carcinoma in the Belgian Shepherd dog. Journal of Small Animal Practice, v.32, n.9, p.465-469, 1991.

SULLIVAN, M.; LEE, R. A study of 31 cases of gastric cancer in dogs. The Veterinary Record, v.120, n.4, p.79-83, 1987.

TERAMACHI, K.; KANOMATA, N.; HASEBE, T. et al. Carcinosarcoma (pure endocrine cell carcinoma with sarcoma components) of the stomach. Pathology International, v.53, p.552556, 2003.

WANG, E.A.; ROSEN, V.; D'ALESSANDRO, J.S. et al. Recombinant human bone morphogentic protein induces bone formation. Proceedings of the National Academy of Sciences USA, v.87, n.6, p.2220-2224, 1990. 